\title{
OCCIPITAL LOBE EPILEPSY OR MIGRAINE HEADACHE
}

\author{
Skrijelj E. Fadil, Mulic Mersudin \\ State University of Novi Pazar, Novi Pazar, Serbia
}

Primljen/Received 17. 07. 2016. god.

Abstract: Introduction: Occipital lobe epilepsies are rarely met in clinical practice, but when they occur, they can be misdiagnosed as migraine-like headache. Their prevalence ranges from $5 \%$ to $10 \%$ of all epilepsies. Seizures can occur at any age; etiologically speaking they can be symptomatic, cryptogenic and idiopathic (most often onsetis in childhood). Clinical symptomatology is manifested by partial epileptic seizures in the sense of visual elementary and/or complex manifestations, palinopsia, amaurosis, tonic head deviation, bulbus, nistagmus and headache. Propagation discharge to neighbour areas (temporal, parietal and frontal) is a frequent occurrence appearing with complex partial seizures frequently finishing with secondary generalized tonic-clonic (GTC) seizures. Case report: We are presenting a17-year-old male patient who has suffered from attacks of visual problems with headache since 10 years of age. All the time it is treated as a migraine headache. During the last attack of headache the patient also had a loss of consciousness, EEG that was performed for the first time evidenced epileptic discharges of the occipital area.The therapy also included treatment with antiepileptic drug pregabalin resulting in seizure withdrawal. Conclusion: The appearance of visual symptoms followed by headache is most frequently qualified as migraine triggered headache. However, when antimigraine therapy does not give favorable results epileptic headache should be suspected, with obligatory performance of EEG recording. Occipital lobe epilepsy often presents diagnostic dilemmas due to clinical manifestations that are similar to that of non-migraine headache.

Key words: headache, migraine, epilepsy, occipital epilepsy, dilemma, diagnosis, EEG recording.

\section{INTRODUCTION}

Epilepsies with seizures generated from the occipital lobe (occipital epilepsies) represent a rare clinical manifestation. Their prevalence rates from $5 \%-10 \%$ of all epilepsies (1). Etiologically speaking they can be
Prihvaćen /Accepted 25. 08. 2016. god.

symptomatic, cryptogenic occurring in all ages, and idiopathic that as a rule occur in childhood (1). Seizures are the most often simple partial, while the occurrence of complex seizures is frequently the sign of extra-occipital propagation discharges (temporal, parietal or frontal lobe). A short duration of seizures lasting from a few seconds to one minute and sometimes even three minutes is characteristic, but very rarely longer. Seizures occur frequently, sometimes every day. Clinical semiology of seizures involves visual and oculomotor symptoms. Visual symptomatology is predominated by elementary, rarely complex visual hallucinations, illusions, palinopsia and amaurosis. Visual hallucinations often appear in the form of small colorful circles that move within the visual field or are rarely shining and of twinkling pulsating lights (2). Elementary visual hallucinations are often followed by oculomotor symptoms with a contralateral tonic deviation of the eyes and head, and epileptic nistagmus with pulsating movements. Headache is often associated with seizures deriving from the occipital area that can be ictal or postictal and often has migraine characteristics. Visual hallucinations are the key symptom that suggests the occipital focus. If the visual symptoms are not expressed, semiology of seizures and standard EEG can be often the cause of misdiagnosed type of epilepsy, because they express more the propagation discharge and less initial locality (3). The occurrence of ictal discharge propagation to neighbor areas is very frequent in symptomatic etiology, but very rare in idiopathic etiology (3). Spreading of seizures can lead to the occurrence of complex partial seizures (temporal and frontal lobes), hemiclonic and GTC seizures. Epileptic seizures of the occipital lobe occur more frequently in the awake than in the sleeping state, the interictal EEG shows occipital spikes and/or the spike-and-wave complex in $57 \%$ of cases, unilaterally or bilaterally (4). Bioccipital discharges of the spike-and-wave complex occur both in symptomatic and idiopathic etiology. In symptomatic epilepsies of the occipital lobe various samples predominate, beginning from congenital mal- 
formations, vascular lesions (infarction, periventricular leukomalacia, porencephaly, hemorrhagic types) systemic diseases, metabolic disorders, infections and neoplasms (4). Prognosis is favorable in the idiopathic and unfavorable in the symptomatic epilepsy where it essentially depends on the type and size of lesion cause. Pharmacoresistance is seen in most symptomatic cases with a disorder of cortical development or occipital lobe tumor where surgical treatment is the method of choice. As the consequence of focal affection of any occipital lobe, visual elementary hallucinations with associated headache can occur that often results in diagnostic dilemma, regardless if it is the case of occipital lobe epilepsy or migraine $(5,6)$. Migraine (hemicrania) is a vascular, unilateral, gradual, most often throbbing and pulsating headache followed by vomiting, photophobia and phonophobia, and which is of various duration ranging from 4-72 hours. Migraine is most frequently a neurological disease with the prevalence of $6 \%-16 \%$. Two major clinical types are migraine without aura $(80 \%)$ and migraine with aura $(20 \%)(7,8)$. The migraine aura is most often expressed by twinkling lights, scotomes, including black-and-white zig-zag lines or amaurosis in duration of 15-60 minutes that is followed by headache. Migraine, and particularly a migraine with aura, is frequently difficult to differentiate from the epilepsy of the occipital lobe due to their similar clinical symptomatology $(9,10)$.

\section{CASE REPORT}

We present a 17 -year male patient born at term and with normal early psychomotor development, without data on hereditary epilepsy, and who had attacks of short-lasting visual problems (shiny color spots, poor vision or complete loss of vision followed by unilateral back head headache. Seizures occurred 2-3 times per week with associated headache of various duration, 1/2-4 hours, and sometimes longer. Standard biochemical and biohumoral laboratory analyses of blood and urine were performed, as well as neurological and ophthalmological examination, CT and MRI that were within the range of normal referent values. Having all this in mind, the diagnosis of migraine with aura was made. All the time the patient was treated with standard antimigraine medications (sumatripan, pizotiphen, propanolol, naproxen, aspirin) but without significant therapeutic effects. It was at this point of time, when during headache loss of consciousness occurred (GTK seizure), that the first EEG was done which showed epileptic discharges of the occipital area (1-3 seconds unilateral spike and spike - wave discharge), apropos occipital epilepsy. The treatment also included antiepileptic pregabalin $(150 \mathrm{mg}+0+150 \mathrm{mg})$, resulting in complete remission seizures.

\section{DISCUSSION}

Epilepsies of the occipital lobe are a typical representation of focal epilepsies that are characterized by ictal aura (subjective ictal phenomenon) with predominant visual symptomatology associated with headache. The specificity of occipital epilepsies is elementary visual hallucinations in the form of small multicolor moving circles that increase and multiply, their rapid occurrence and short duration from a few seconds to 3-4 minutes $(1,5)$. Beside the short-lasting visual aura attacks, occipital epilepsies are characterized by ictal or postictal migraine triggered headache (unilateral or bilateral, pulsating, nausea) that is various in duration, lasting from several minutes to several hours or longer. Identical clinical symptomatology can be also seen in migraines with aura, with the migraine aura developing slowly, lasting longer ( $\geq 5$ minutes) and is mostly followed by colorless visual symptoms in the sense of black-and-white zig-zag lines or scotoma. Migraine headache follows the migraine aura mostly lasting 4-72 hours $(7,8)$. Migraine and occipital epilepsies have a paroxysmal beginning and a great number of common symptoms that often creates a problem of their diagnostic differentiation. Therefore, in practice it is quite frequent that epilepsy of the occipital lobe is to be proclaimed as a migraine with aura, and more rarely the opposite. These diagnostics mistakes are not rare and can be found in numerous reports by many authors $(5,6)$. Although the visual aura and headache have their specificities both in the speed of their development and the time of duration, they cannot be often significant parametric differentiating factors between epilepsy and migraine (8). The thing, that can clearly differentiate occipital epilepsies from migraine is the manifestation of ictal oculomotor symptomatology in the sense of the deviation of the head, eyes, nistagmus or hemiconvulsions, GTC seizures and EEG epileptic discharges (5). EEG is the main and irreplaceable diagnostic test for disorders which in occipital epilepsies interictally often register unilateral and/or bilateral occipital epileptic discharges in the appearance of spike and/or spike-and-waves. Therefore, it is necessary to perform EEG in all atypical, persistent headaches, migraine that does not react to standard analgesics and antimigraine medications. In migraines EEG most often shows unspecific, non-epileptiform changes, however if specific grapho-elements are registered it is clear that there is the presence of epileptic headache $(7,8)$. The term "migralepsy", which is still used today in the terminology of headaches, and indicates the epileptic seizure during or after the migraine aura, is increasingly often changed by the term epileptic headache hemicrania epileptic, which suggests that the headache 
is, for example, primarily of epileptic and not of migraine etiology $(6,11)$. Headaches are often nonspecific clinical manifestations of epilepsy; they frequently develop as the result of general organism and brain fatigue after GTC seizure. In relation to the epileptic seizure, in epilepsies headaches are classified as preictal (prodrom seizures), ictal, postictal and interictal (10, 11). In the epilepsies of the occipital lobe, headache is a frequent manifestation showing characteristic of seizures; inctalare of shorter duration, while the postictal last longer and have the characteristics of migraine. Investigations have shown that migraine and epilepsy use common pathophysiological mechanisms and genetic factors which make them clinically similar and diagnostically difficult to differentiate (12). It is clear that the onset of the occipital lobe epilepsy is not essentially different from the migraine with aura, however other clinical manifestations, EEG, CT and MRI findings and response to drug treatmentcan be of significant help in the differentiation between epilepsy and migraine. Our case report also confirms that epileptic seizures (epilepsy of the occipital lobe) are frequently misdiagnosed as migraine. Beside the frequent practice of epileptic seizures being pronounced as an epileptic seizure (event) there are also the opposite situations. About $20 \%-30 \%$ of cases that are hospitalized in the specialized institutions for epilepsy do not have epilepsy, and instead have an epileptic seizure, mostly in the form of a syncope, vertigo, transitory ischemic attack, migraine, parasomnia, dyskinesia or psychogenic nonepileptic seizure $(13,14,15)$.

\section{CONCLUSIONS}

Clinical occurrence of visual symptoms and the associated headaches are more frequently qualified as migraine triggered headache. However, if the migraine therapy does not yield favorable results it is also necessary to suspect epilepsy of the occipital lobe. The epilepsy of the occipital lobe often leads to a diagnostic dilemma due to clinical manifestations which are similar to non-migraine type of headache. Visual symptomatology and headache characterize both clinical entities. However, the knowledge of further symptomatology with the application of the necessary examination protocol (EEG, MRI) considerably helps in their diagnostic differentiation and exact diagnosis.

\section{Conflict of interest}

Authors confirmed that no actual or potential conflict of interest exists in relation to this article.

\section{Source of Funding}

There were no external funding source for this study.
Abbreviations
GTC - generalized tonic-clonic
EEG - electroencephalography
CT - computed tomography
MRI — magnetic resonance image

\title{
Sažetak
}

\section{EPILEPSIJA OKCIPITALNOG REŽNJA ILI MIGRENSKA GLAVOBOLJA}

\author{
Škrijelj E. Fadil, Mulić Mersudin \\ Državni Univerzitet u Novom Pazaru, Novi Pazar, Srbija
}

Uvod: Epilepsije okcipitalnog režnja se retko sreću u kliničkoj praksi, a kada se pojave mogu biti pogrešno dijagnostikovane kao migrenska glavobolja. Prevalencija im se kreće od 5\% do 10\% svih epilepsija. Napadi se mogu javiti u svakom uzrastu, a etiološki mogu biti simptomatske, kriptogene i idiopatske (najčešči početak u detinjstvu). Klinička simptomatologija se manifestuje parcijalnim epileptičkim napadima $u$ smislu vizuelnih elementarnih i/ili složenih halucinacija, palinopsije, amauroze, tonične devijacije glave, bulbusa, nistagmusa i glavobolje. Propagacija pražnjenja na susedne regione (temporalni, parijetalni i frontalni) je česta pojava, pri čemu dolazi do složenih parcijalnih napada koji se često završe sekundarnim GTK napadima. Prikaz bolesnika: Prikazali smo muškog pacijenta, uzrasta od 17 godina, koji od svoje 10. godi- ne ima napade vizuelnih smetnji sa glavoboljom. Sve vreme tertian je kao migrenska glavobolja. Kada je tokom poslednjeg napada glavobolje imao i gubitak svesti urađen je prvi put EEG snimak koji je ukazao na epileptička pražnjenja okcipitalnih regiona. U terapiju je uključen antiepileptic pregabalin i napadi su prestali. Zaključak: Pojava vizuelnih simptoma sa pratećom glavoboljom se najčešće kvalifikuje kao migrenska glavobolja. Međutim, kada antimigrenska terapija ne daje povoljne rezultate, potrebno je posumnjati i na epileptičku glavobolju uz neophodno EEG snimanje. Epilepsije okcipitalnog režnja često prave dijagnostičke dileme zbog kliničkih manifestacija koje su slične migrenskoj glavobolji.

Ključne reči: glavobolja, migrena, epilepsija, okcipitalna epilepsija, dilema, dijagnoza, EEG snimanje. 


\section{REFERENCES}

1. Panayiotopoulos CP. A Clinical Guide to Epileptic Syndromes and their Treatment. 2nd Ed. London: Springler Healthcare Ltd, 2010. p. 135-47.

2. Taylor I, Scheffer IE, Berkovic SF. Occipital epilepsies: Identification of specific and newly recognized syndromes. Brain. 2003; 126 (4): 753-69.

3. Kuzniecky R. Symptomatic occipital lobe epilepsy. Epilepsia. 1998; 39(Suppl 4): S24-31.

4. Jobst BC, Williamson PD, Thadani VM, et al. Intractable occipital lobe epilepsy: Clinical characteristics and surgical treatment. Epilepsia. 2010; 51(11): 2334-7.

5. Panayiotopoulos CP. Elementary visual hallucinations, blindness and headache in idiopathic occipital epilepsy, differentiation from migraine. J Neurol Neurosurg Psychiatr. 1999; 66(4): 536-40.

6. Caraballo R, Koutromanidis M, Panayiotopoulos CP, Feirmann N. Idiopathic childhood occipital epilepsy of Gastaut: a review and differentiation from migraine and other epilepsies. J Child Neurol. 2009; 24(12): 1530-42.

7. Vujisic S, Radulovic L, Vodopic S. Comorbidity of epilepsy and migraines epidemiological and clinical aspects. Sanamed. 2012; 7(2): 79-84.

\section{Correspodence to/ Autor za korespodenciju}

Fadil E. Škrijelj MD, PhD

State University of Novi Pazar

str. V. Karadzica bb, Novi Pazar, Serbia

Telephone: +38163687 743

E-mail: skrijeljneuro@gmail.com
8. Kabakus IM, Kabakus N. Epilepsy Mimicking Migraine: Is It Migralepsy? Sch J Med Case Rep. 2014; 2(6): 386-8.

9. Dainese F, Mai R, Francione S, Mainardi F, Zanchin G, Paladin F. Ictal headache: headache as first ictal symptom in focal epilepsy. Epilepsy Behav. 2011; 22(4): 790-2.

10. Cianchetti C, Pruna D, Ledda M. Epileptic seizures and headache/migraine: a review of types of association and terminology. Seizure. 2013; 22(9): 679-85.

11. Kasteleijn-NolstTrenite D, Parisi P. Migraine in the borderland of epilepsy: "migralepsy" an overlapping syndrome of children and adults? Epilepsia, 2012; 53 (Suppl 7): 20-5.

12. Winawer MR, Connors R, EPGP Investigators. Evidence for a shared genetic susceptibility to migraine and epilepsy.Epilepsia. 2013; 54(2): 288-95.

13. La France WCJr, Duncan R, Reuber M, Goldstein LH, Baker GA. In response to comments on parietal seizures mimicking psychogenic nonepileptic seizures. Epilepsia. 2014; 55(1): 197-8.

14. Skrijelj F, Mulic M. Aggravation of symptomatic occipital epilepsy of childhood by carbamazepine. Vojnosanit Pregl. 2014; 71(4): 404-7.

15. Berra E, Sances G, De Icco R, et al. Cost of Chronic and Episodic Migraine. A pilot study from a tertiary headache centre in northern Italy. J Headache Pain. 2015; 16:532. 